\title{
Potential role of endogeic earthworm Pontoscolex corethrurus in remediating banana blood disease: a preliminary observation
}

\begin{abstract}
Blood disease is a destructive bacterial infection that causes severe yield loss to the banana industry. Ideally, an environmental friendly yet practical approach is necessitated in the search for effective treatment against the disease. Endogeic earthworms are soil biota that help in improving soil physico-chemical and biological properties and thuspromote plant health. The present study assessed the effect of Pontoscolex corethrurus on banana infected by blood disease. The effect of earthworms was evaluated through observations on stem and root morphology, anatomy and total phenolic contents (TPC). P. corethrurus was inoculated into polybags planted with banana plantlets; inoculation of blood disease bacterium (BDB) into the roots of the plantlets was done using a drenching method. Stem and root sections of the plantlets were preserved in FAA for histological study upon harvest. The remaining sections were freeze-dried for TPC analysis. Root sections of plantlets infected with BDB showed lower root biomass compared to the control and earthworm-inoculated plantlets. Observations under microscope also showed that tissue necrosis at the vascular bundles of infected roots were more severe compared to the earthworm-inoculated and unaffected plantlets. Plantlets inoculated with earthworms had the highest root TPC, followed by the unaffected plantlets and plantlets infected with BDB. Although infected plantlets with earthworm inoculation showed disease symptoms, the disease severity was slightly less. The results suggested the potential role of P. corethrurus in improving plant health for disease management and sustainable agriculture.
\end{abstract}

Keyword: Banana; Blood disease bacterium (BDB); Earthworm; Pontoscolex corethrurus 